\title{
Effect of selective dorsal rhizotomy for treatment of spasticity related to cere- bral palsy - report on one-year postoperative results in the Polish population
}

\section{Zastosowanie selektywnej rizotomii grzbietowej w leczeniu spastyczności związanej z mózgowym porazeniem dziecięcym - ocena wyników leczenia w populacji polskiej rok po operacji}

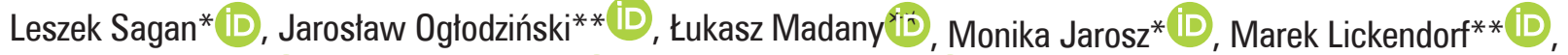 \\ Paweł Małasiak**(D), Konrad Jarosz ${ }^{* * *(D)}$, Ernest Tyburski****iD) \\ *Department of Neurosurgery and Pediatric Neurosurgery, Pomeranian Medical University, Szczecin \\ **Devision of Pediatric Neurosurgery, Pomeranian Medical University, Szczecin, ***Department of Anesthesiology, Pomeranian \\ Medical University, Szczecin, ${ }^{* * *}$ Institute of Psychology, SWPS University of Social Sciences and Humanities, Poznan \\ DOI:10.20966/chn.2020.58.454
}

\section{ABSTRACT}

Aim: Selective dorsal rhizotomy (SDR) is a form of surgical treatment that reduces tone in lower extremities by selective sectioning of lumbosacral dorsal roots fibers. However, the method occasionally still arouses some controversies. Since it was introduced in Poland, relatively recently, the discussion on its efficacy is even more vivid. To address this issue we present the analysis of patients treated with SDR in our institution.

Material and methods: Out of 96 operated patients 76 were eligible for the study and 30 of them showed up for one-year follow up and were finally analyzed. Modified Ashworth Scale (MAS) was used to measure spasticity and the Gross Motor Function Measure (GMFM) to asses gross motor functioning of the patients.

Results:

For spasticity of different muscles measured by MAS there were significant differences between pre-treatment and post-treatment $(p<0.05$, after Holm-Bonferroni correction; effect size $1.26<d>2.32$ ). Furthermore, for gross motor functioning measured by GMFM, there was significant difference between both time points treatment $(d=0.68)$.

Conclusions:

To our knowledge this is the first report on results of SDR for cerebral palsy treatment in Polish population. The treatment significantly diminished spasticity and improved gross motor functioning on the long term basis. This should provide reassurance to parents considering the procedure and influence the discussion on including SDR in the group of neurosurgical procedures founded by health system authorities in Polandneurodegenerative and metabolic diseases are suspected, genetic testing is performed. Despite the progress that has been made in treating some ataxia disorders in recent years, with few exceptions, for most of patients the therapy of choice is symptomatic and supportive treatment.

Key words: selective dorsal rhizotomy, cerebral palsy, spasticity, gross motor function.

\section{STRESZCZENIE}

Cel: Selektywna rizotomia grzbietowa (SDR) jest neurochirurgiczną metodą leczenia spastyczności w mózgowym porażeniu dziecięcym (CP). Pomimo udowodnionej efektywności jej stosowanie budzi czasem kontrowersje dotyczące inwazyjności metody w stosunku do poprawy funkcjonowania chorych. SDR została w Polsce wprowadzona stosunkowo niedawno, stąd też powyższe wątpliwości budzą szczególnie żywą dyskusję w odniesieniu do naszej populacji. Celem odpowiedzi na rodzące się pytania kliniczne przedstawiamy analizę wyników leczenia metodą SDR grupy chorych operowanych w naszym ośrodku. Materiał i metody: Spośród 96 chorych leczonych operacyjnie metodą SDR, 76 spełnito kryteria włączenia do badania. Z tej grupy, 30 chorych zgłosiło się na kompleksową ocenę wykonywaną rok po operacji i zostało ostatecznie poddanych analizie. Oceniano stopień spastyczności opisując ją Zmodyfikowaną Skalą Ashwortha (Modified Ashworth Scale -MAS) oraz ogólne funkcjonowanie motoryczne stosując Skalę Funkcjonalną Motoryki Dużej (Gross Motor Function Measure - GMFM).

Wyniki: Dla spastyczności różnych partii mięśniowych mierzonych za pomocą MAS wykazano istotne różnice przed leczeniem i po leczeniu ( $p<0,05$, po korekcie Holm-Bonferroniego; wielkość efektu $1,26<d>2,32$ ). Ponadto dla ogólnego funkcjonowania motorycznego mierzonego skalą GMFM wykazano znaczącą różnicę między oboma pomiarami $(\mathrm{d}=0,68)$.

Wnioski: Według wiedzy autorów jest to pierwsze doniesienie dotyczące skuteczności leczenia operacyjnego metodą SDR spastyczności związanej z CP w polskiej populacji. Operacja znacznie zmniejszyła spastyczność i poprawiła ogólne funkcjonowanie motoryczne, a efekt ten utrzymywał się długotrwale. Uzyskane rezultaty powinny być brane pod uwage $\mathrm{w}$ wyborze metody leczenia spastyczności u dzieci z CP, a także stanowić przyczynek do dyskusji systemowej nad włączeniem SDR do grupy procedur neurochirurgicznych zarejestrowanych w Polsce.

Słowa kluczowe: selektywna rizotomia grzbietowa, dziecięce porażenie mózgowe, spastyczność, motoryka duża.

\section{INTRODUCTION}

Cerebral palsy (CP) has a prevalence of 2-3 per 1000 live births and leads to broad spectrum of disabilities of which spasticity is one of the more prominent [1]. The spasticity is caused by perinatal damage to the periventricular white matter and subsequent reduction of higher level inhibito- ry input into the spinal cord alpha motor neurons activity. Uninhibited afferent roots input excessively stimulates these pool of neurons leading to spasticity. A number of interventions is available for the management of spasticity in CP. The treatment can be conservative or surgical, temporary or permanent and focal or generalized. Selective 
dorsal rhizotomy (SDR) is a form of surgical treatment that permanently reduces tone in lower extremities by selective sectioning of lumbosacral dorsal roots fibers. From all the available methods this is the one which is the closest to treat the cause and not the symptom of the pathology. The technique is well established as a treatment in cerebral palsy [2-4]. However, occasionally it still arouses some controversies, especially in respect to its invasiveness versus functional efficacy. Despite that the method brings immediate reduction of spasticity, gradual improvement of gross motor function and reduction of future surgical corrections of tendons and joints, there is still discussion regarding selection criteria for this treatment [5-7]. SDR was introduced in Poland on systematic basis just a few years ago, therefore the problems mentioned above are even more vividly discussed in respect to our population. To address these issues we present the analysis of patients treated with SDR in our institution.

\section{MATERIAL AND METHODS}

All patients recruited for the study were treated for $\mathrm{CP}$ related spasticity using SDR at theDivision of Pediatric Neurosurgery, Department of Neurosurgery, Pomeranian Medical University, "Zdroje" Hospital. The study population was composed of patients who were evaluated preoperatively and one year after surgery by the multidisciplinary team (neurosurgeon, neurologist, physiotherapist). Data were collected prospectively between 2013 and 2018 .

\section{Preoperative selection criteria}

Eligibility criteria for the surgery were as follows: age 3 to 18 years, spastic lower paraparesis, hemiparesis or tetraparesis, fair to good trunk and head control (ability for high kneeling for at least 5 seconds), no bulbar involvement, absence of other significant neurological motor abnormalities such as dystonia, ataxia or athetosis, good prognosis for ambulation, cooperative functioning, absence of uncontrolled epilepsy, normal spine anatomy and no hips dysplasia. The spasticity had to be at the level causing negative consequences, including progressive deformities and gait deterioration.

\section{Clinical assessment}

For spasticity measurement the Modified Ashworth Scale (MAS) was used [8]. The MAS is a scale constructed to evaluate the change in muscle spasticity and is composed of three general dimensions: dimension 1 (hip muscle tone, right and left), dimension 2 (knee muscle tone, right and left), and dimension 3 (ankle muscle tone, right and left). To asses the level of tone increase the modified rating proposed by Bohannon and Smith [9] (0 point, 1, point 1+ point, 2 point, 3 point and 4 point) was implemented. The MAS has a good psychometric parameters i.e. validity and reliability $[10,11]$. In our study the scores were analysed in all dimensions and transformation was used to transform the raw scores of variables (type of the muscle tone dysfunction) to scaled scores (from 1 point to 6 point).

For motor function assessment a widely recognized test, the Gross Motor Function Measure (GMFM), was used [12]. The GMFM is a scale constructed to evaluate the change in gross motor function in children with cerebral palsy. This scale consists of five dimensions, i.e., dimension A (lying and rolling), dimension B (sitting), dimension $\mathrm{C}$ (crawling and kneeling), dimension $\mathrm{D}$ (standing) and dimension $\mathrm{E}$ (walking, running, and jumping). It has been shown that the GMFM had a good psychometric parameters i.e. validity, reliability and responsiveness [13].

In our study we summarised percentage of the maximum score for all dimensions.

\section{Surgical procedure}

Anesthesia was induced in all patients by a mixture of sufentanil and propofol which was infused along with nitrous oxide. Spinal roots from L1 to S1 were exposed through L1-L5 laminoplasty or three level laminoplasty flap just below the level of connus medullaris position. The dorsal roots from L1 to S1 were anatomically identified and separated from the ventral roots. The innervation pattern of each root was examined using EMG testing. The entire root was placed over two hooked electrodes and responses to electrical stimulation were recorded from the lower extremities muscles. The stimulus intensity was increased gradually until the reflex response appeared from the lower extremity thus threshold of the stimulation was determined. Subsequently the root was divided to fascicles and every of the fascicles was stimulated by hook electrodes with a $50-\mathrm{Hz}$ train tetanic stimulation for $1 \mathrm{sec}$. Muscles responses were classified according to EMG grading criteria in SDR for CP [14]. At the same time the physiotherapist observed the character of lower extremities movement. The decision to cut a particular fascicle was based on the type of those two responses (spread of the reflex recorded at EMG and the character of lower extremities movement observed by physiotherapist). The same procedure was performed bilaterally for each root from L1 to S1. The dura was closed with running stitches and laminotomy flap fixed to the vertebra with osteoplastic titanium plates. The wound was sutured with layers.

\section{Postoperative care}

Postoperatively patients were cared for in bed rest for 48 hours. Analgesia was maintained with regular paracetamol and intravenous opiate. A urinary catheter was usually kept for three days when mobilization was started. On the 3rd day after SDR an inpatient rehabilitation program was started. The physical therapy was led by two physiotherapists dedicated to postoperative rehabilitation of patients with cerebral palsy. On the 7 th - 10th postoperative day skin suture was removed and the patient was discharged home with written suggestion of personalized outpatient program for further physical therapy provided by local patient's rehabilitation centers. Follow-up examination was undertaken at 6 months after the surgery but patients had open access for advice during that period. Twelve months after the surgery patients were invited for one day ambulatory visit for physiotherapeutic assessment and examination with GMFM and Ashworth scale. 


\section{Statistical analysis}

Statistical analysis was performed using the IBM SPSS 25 Statistical package. Continuous variables are presented in the form of means (M) and standard deviations (SD). The normality of the distribution of the variables was verified using the Shapiro-Wilk test. Dependent Student's t-test for paired samples (with bootstrap procedures of 1000 samples) were conducted to evaluate the change of the clinical status of patients between pre-treatment and post-treatment. To determine the magnitude of effect size, Cohen's d effect size was used [15]. Holm-Bonferroni p-value correction for multiple comparisons was used [16].

\section{RESULIS}

According to the procedure used in our institution all patients undergoing SDR are called in for complex examination one year after surgery. Out of 96 operated patients 76 had complete preoperative GMFM and Ashworth scale records and were eligible for the study. All of them were invited for one-year postoperative complex follow-up assessment and, finally, 30 of them showed up for the visit and were enrolled in the study. There were 22 males and 8 females, aged from 3 to 18 years old $(M=9.00 ; S D=4.14)$.

Table I Comparison of the patients clinical status in the first and second testing Tabela I Porównanie stanu klinicznego pacjentów w pierwszym i drugim pomiarze

\begin{tabular}{|c|c|c|c|c|c|c|c|c|}
\hline \multirow{2}{*}{ Variable } & \multicolumn{2}{|c|}{ Pre-treatment } & \multicolumn{2}{|c|}{ Post-treatment } & \multirow[t]{2}{*}{$t$} & \multirow[t]{2}{*}{$p^{\mathrm{a}}$} & \multirow[t]{2}{*}{$p^{\mathrm{b}}$} & \multirow[t]{2}{*}{$d$} \\
\hline & $M$ & $S D$ & $M$ & $S D$ & & & & \\
\hline \multicolumn{9}{|c|}{ Different hip muscle tone on MAS } \\
\hline Left hip extension & 3.67 & 1.56 & 1.67 & 0.92 & 8.89 & 0.001 & 0.025 & 1.62 \\
\hline Right hip extension & 3.77 & 1.52 & 1.70 & 0.95 & 9.00 & 0.001 & 0.025 & 1.64 \\
\hline Left hip flexion & 3.27 & 1.48 & 1.20 & 0.48 & 8.31 & 0.001 & 0.025 & 1.52 \\
\hline Right hip flexion & 3.33 & 1.42 & 1.23 & 0.50 & 9.27 & 0.001 & 0.025 & 1.69 \\
\hline Left hip abduction & 3.73 & 1.46 & 1.27 & 0.58 & 10.35 & 0.001 & 0.025 & 1.89 \\
\hline Right hip abduction & 3.73 & 1.55 & 1.30 & 0.65 & 9.65 & 0.001 & 0.025 & 1.76 \\
\hline Left hip adduction & 3.07 & 1.34 & 1.17 & 0.53 & 8.58 & 0.001 & 0.025 & 1.57 \\
\hline Right hip adduction & 2.97 & 1.38 & 1.13 & 0.43 & 7.79 & 0.001 & 0.025 & 1.42 \\
\hline Left hip external rotation & 3.63 & 1.40 & 1.50 & 0.68 & 10.57 & 0.001 & 0.025 & 1.93 \\
\hline Right hip external rotation & 3.57 & 1.38 & 1.70 & 0.92 & 9.82 & 0.001 & 0.025 & 1.80 \\
\hline Left hip internal rotation & 3.60 & 1.48 & 1.37 & 0.80 & 9.19 & 0.001 & 0.025 & 1.68 \\
\hline Right hip internal rotation & 3.63 & 1.50 & 1.33 & 0.71 & 9.04 & 0.001 & 0.025 & 1.65 \\
\hline \multicolumn{9}{|c|}{ Different knee muscle tone on MAS } \\
\hline Left knee extension & 3.00 & 1.64 & 1.37 & 0.85 & 6.89 & 0.001 & 0.025 & 1.26 \\
\hline Right knee extension & 3.07 & 1.60 & 1.37 & 0.85 & 7.07 & 0.001 & 0.025 & 1.29 \\
\hline Left knee flexion & 3.00 & 1.51 & 1.23 & 0.57 & 7.27 & 0.001 & 0.025 & 1.33 \\
\hline Right knee flexion & 3.00 & 1.53 & 1.23 & 0.57 & 7.13 & 0.001 & 0.025 & 1.30 \\
\hline \multicolumn{9}{|c|}{ Different ankle muscle tone on MAS } \\
\hline Left ankle dorsiflexion & 4.83 & 1.26 & 2.17 & 1.18 & 11.05 & 0.001 & 0.025 & 2.02 \\
\hline Right ankle dorsiflexion & 5.03 & 0.96 & 2.37 & 1.33 & 11.51 & 0.001 & 0.025 & 2.10 \\
\hline Left ankle plantar flexion & 3.70 & 1.42 & 1.33 & 0.71 & 10.41 & 0.001 & 0.025 & 1.90 \\
\hline Right ankle plantar flexion & 3.93 & 1.23 & 1.47 & 0.86 & 12.22 & 0.001 & 0.025 & 2.31 \\
\hline Left extraversion & 3.83 & 1.58 & 1.63 & 0.96 & 9.10 & 0.001 & 0.025 & 1.67 \\
\hline Right extraversion & 4.33 & 1.24 & 1.57 & 0.94 & 12.69 & 0.001 & 0.025 & 2.32 \\
\hline Left introversion & 4.10 & 1.42 & 1.53 & 0.86 & 10.78 & 0.001 & 0.025 & 1.97 \\
\hline Right introversion & 4.43 & 1.19 & 1.53 & 0.78 & 12.23 & 0.001 & 0.025 & 2.23 \\
\hline \multicolumn{9}{|c|}{ Global motor function on GMFM } \\
\hline Summarized percentage of scores & 68.62 & 20.27 & 77.82 & 15.54 & -3.72 & 0.006 & 0.025 & 0.68 \\
\hline
\end{tabular}

Abbreviations: $d$ - Cohen's d effect size: small (0.20-0.49), medium (0.50-0.79), large ( $>0.80)$; GMFM - Gross Motor Function Measure; MAS - Modified Ashworth Scale; M - mean; SD - standard deviation; t - Student's t-test.

${ }^{a} p$-value uncorrected. ${ }^{b} p$-value set at 0.05 for the number of comparisons using Holm-Bonferroni method of correction.

Skróty: $d$ - wielkość efektu Cohena: mała (0,20-0,49), średnia (0,50-0,79), duża (>0,80); GMFM - Skala Funkcjonalna Motoryki Dużej; MAS - Zmodyfikowana Skala Ashwortha; M - średnia; SD - odchylenie standardowe; $t$ - test Student's. ${ }^{a} p$ - wartość p nieskorygowana. ${ }^{b} p$ - wartość ustalona na 0,05 dla liczby porównań metodą korekcji Holma-Bonferroniego 
For different hip muscle tone, knee muscle tone, and ankle muscle tone on MAS there were significant differences between pre-treatment and post-treatment, respectively in all left and right muscles $(\mathrm{p}<0.05)$. The results were presented in Table I, Figure 1, Figure 2, and Figure 3 (for hip muscle tone), Figure 4 (for knee muscle tone), and Figure 5 and Figure 6 (for ankle muscle tone). Large effect sizes were demonstrated for those indicators $(1.26<\mathrm{d}<2.32)$.

Furthermore, for functional muscle measured by GMFM there was significant difference $(p<0.05)$ between pre-treatment and post-treatment. The result was presented in Table I. Medium effect size was demonstrated for this indicator $(\mathrm{d}=0.68)$.

Fig. 1. MAS mean scores for hip muscle tone: extension and flexion at pre-treatment and post-treatment examination. * $p<0.05$ (after Holm-Bonferroni p-value correction).

Tabela. 1. Średnie wyniki w skali MAS dla napięcia mięśni biodrowych: wyprost i zgięcie w badaniu przed i po leczeniu. ${ }^{*} p<0,05$ (po korekcie wartości p metodą Holma-Bonferroniego)

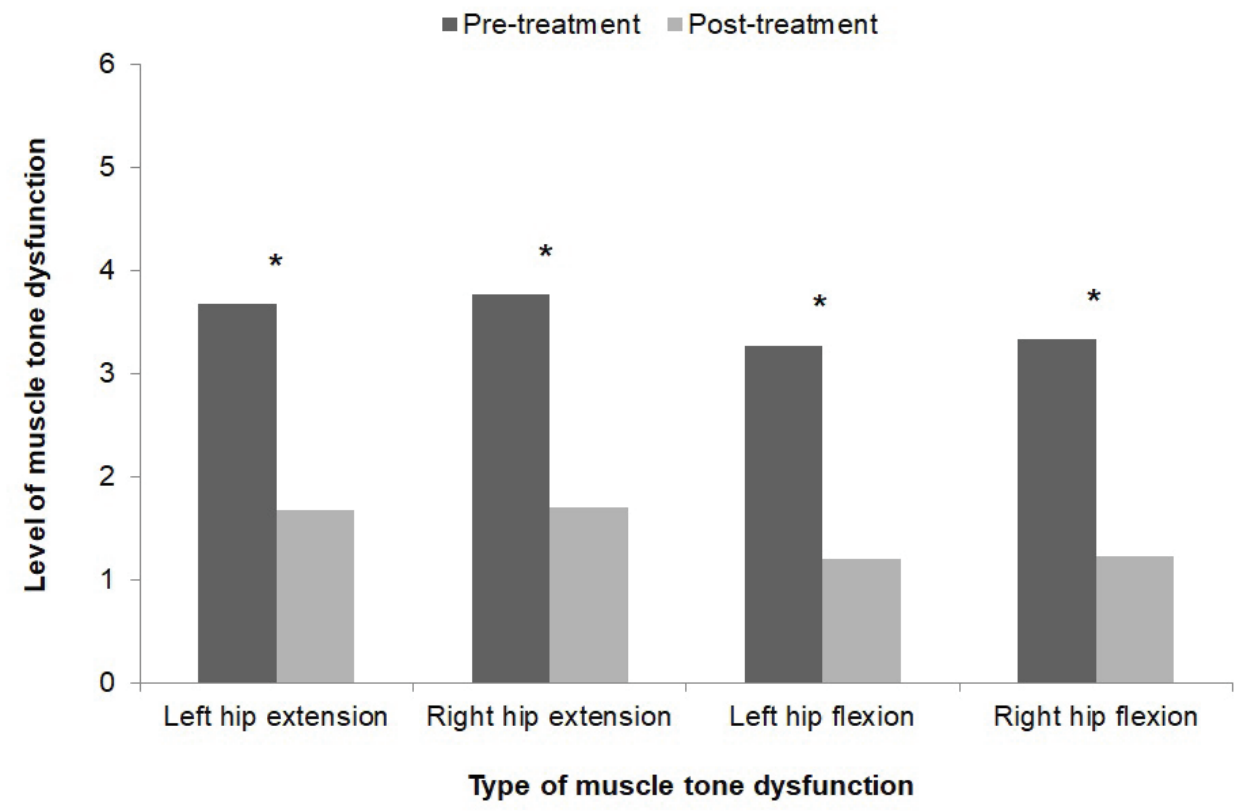

Fig. 2. MAS mean scores for hip muscle tone: abduction and adduction at pre-treatment and post-treatment examination * $\mathrm{p}<0.05$ (after Holm-Bonferroni p-value correction).

Tabela. 2. Średnie wyniki w skali MAS dla napięcia mięśni biodrowych: odwodzenie i przywodzenie w badaniu przed i po leczeniu.

${ }^{*} p<0,05$ (po korekcie wartości p metodą Holma-Bonferroniego)

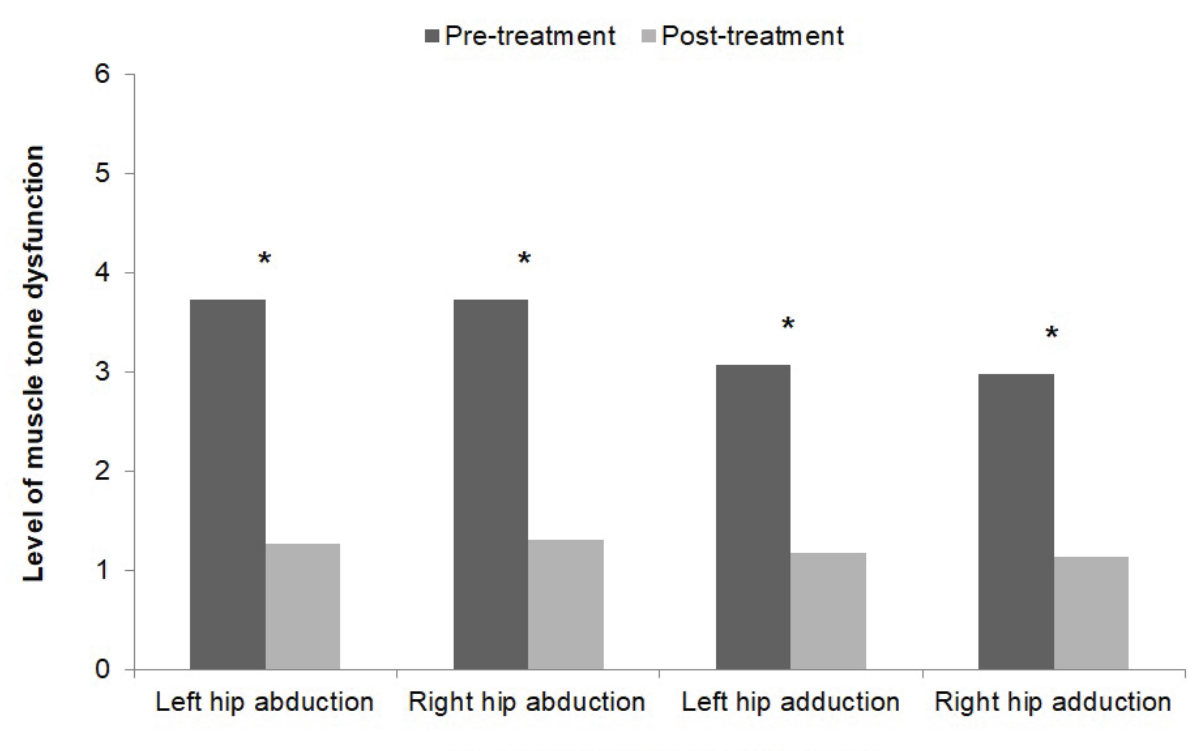

Type of muscle tone dysfunction 
Fig. 3. MAS mean scores for hip muscle tone: external ant internal rotation at pre-treatment and post-treatment examination * $\mathrm{p}<0.05$ (after Holm-Bonferroni p-value correction).

Tabela. 3. Średnie wyniki w skali MAS dla napięcia mięśnia biodrowego: rotacja zewnętrzna i wewnętrzna w badaniu przed i po leczeniu

${ }^{*} p<0,05$ (po korekcie wartości p metodą Holma-Bonferroniego)

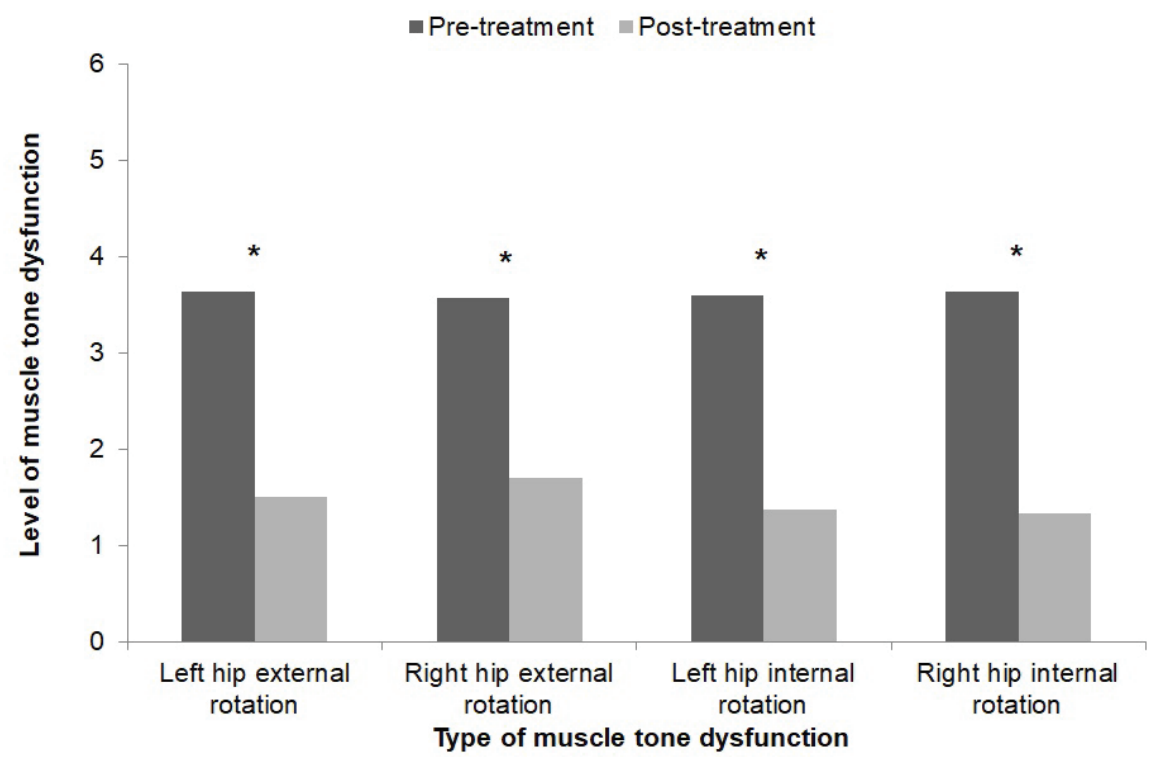

Fig. 4. MAS mean scores for knee muscle tone dysfunction: extension and flexion at pre-treatment and posttreatment examination

${ }^{*} \mathrm{p}<0.05$ (after Holm-Bonferroni p-value correction).

Tabela. 4. Średnie wyniki MAS dla dysfunkcji napięcia mięśni kolana: wyprost i zgięcie w badaniu przed i po leczeniu ${ }^{*} p<0,05$ (po korekcie wartości p metodą Holma-Bonferroniego)

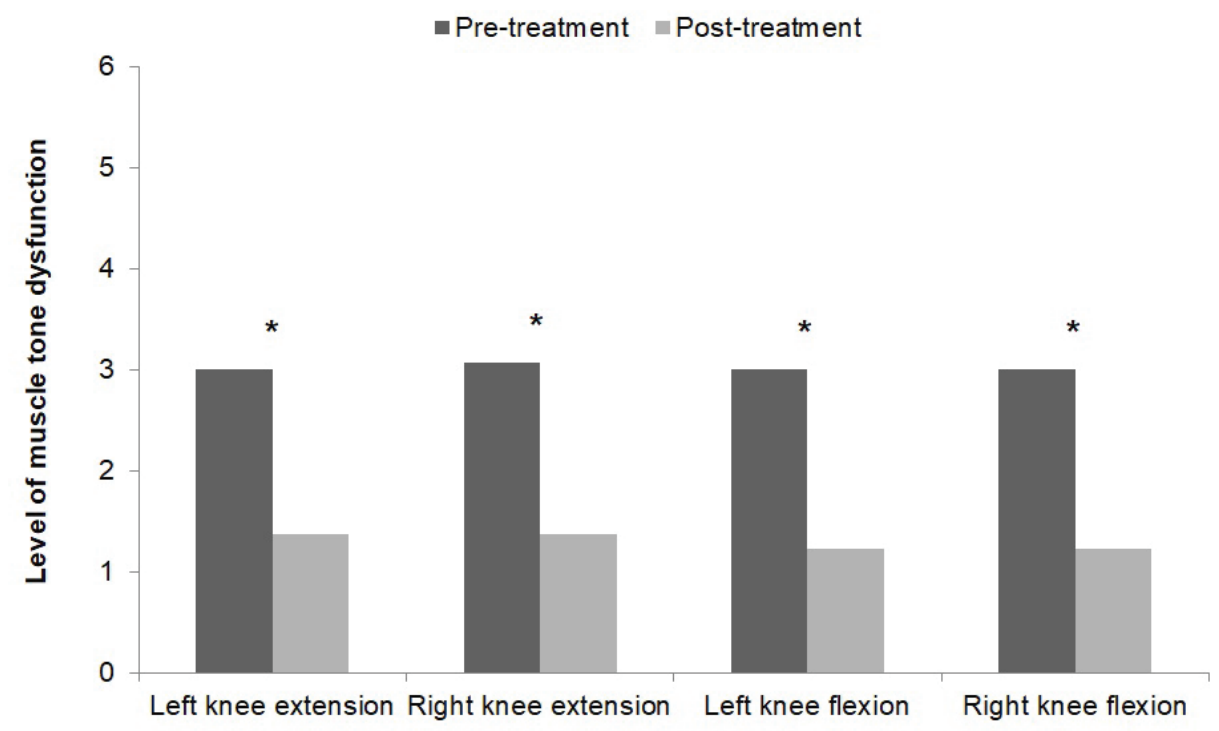

Type of muscle tone dysfunction 
Fig. 5. MAS mean scores for s for ankle muscle tone dysfunction: dorsiflexion and flexion at pre-treatment and posttreatment examination

${ }^{*} \mathrm{p}<0.05$ (after Holm-Bonferroni p-value correction).

Tabela. 5. Średnie wyniki MAS dla dysfunkcji napięcia mięśni mięśni stawu skokowego: zgięcia grzbietowego i zgięcia $w$ badaniu przed i po leczeniu

${ }^{*} p<0,05$ (po korekcie wartości p metodą Holma-Bonferroniego)

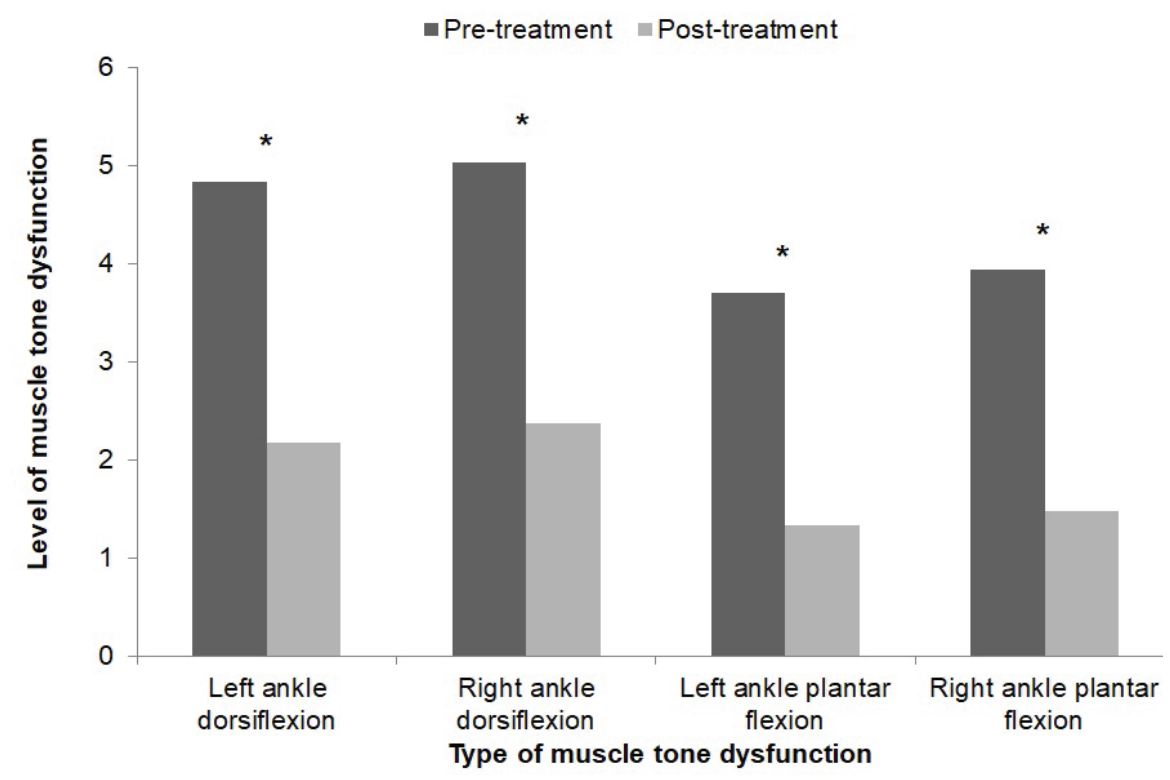

Fig. 6. MAS mean scores for s for ankle muscle tone dysfunction: : extraversion and introversion at pre-treatment and post treatment examination

${ }^{*} \mathrm{p}<0.05$ (after Holm-Bonferroni p-value correction).

Tabela. 6. Średnie wyniki MAS dla dysfunkcji napięcia mięśni stawu skokowego: ekstrawersja i introwersja w badaniu przed i po leczeniu.

${ }^{*} p<0,05$ (po korekcie wartości p metodą Holma-Bonferroniego)

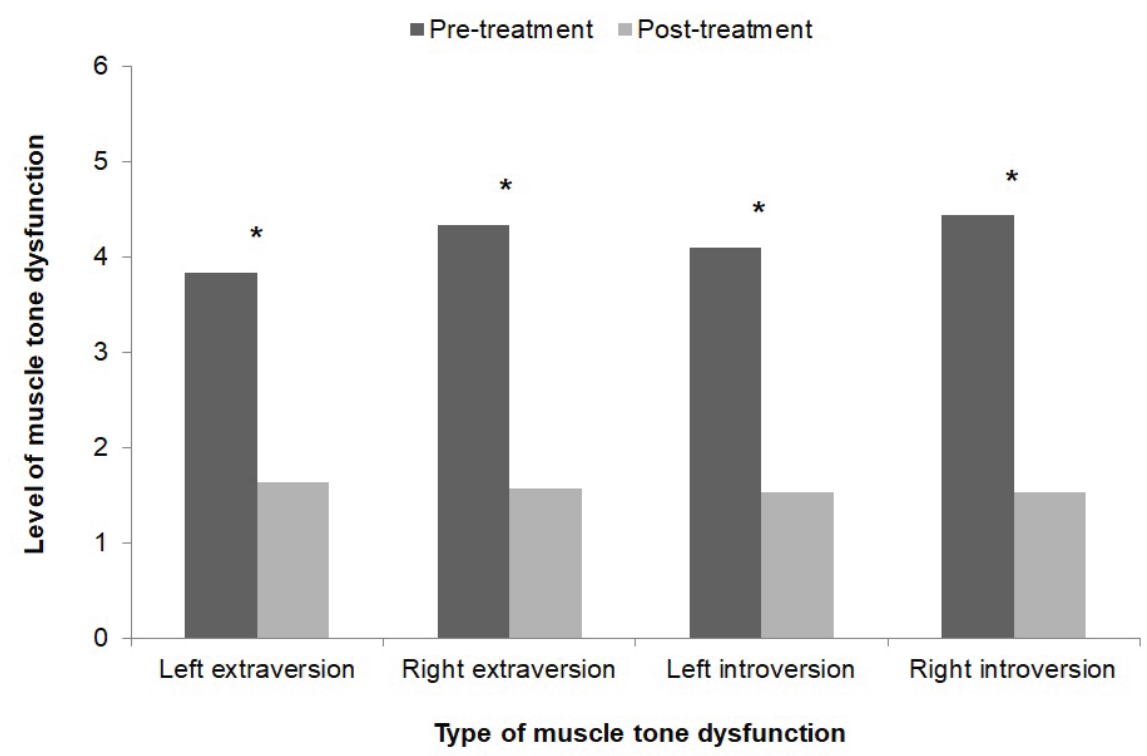

\section{Complications}

There were no serious adverse events. One case of urinary retention that required intermittent catheterization for up to 5 days and one case of wound infection were documented. No cerebrospinal fluid leak or spine deformity was encountered. Majority of patients complained of lower extremities paresthesias subsiding gradually during several days.

\section{DISCUSSION}

Selective dorsal rhizotomy has been used increasingly in many centers all over the world for over 30 years. The goal of SDR is to diminish the velocity-dependent hyper tonicity in lower limbs and improve motor function. Many investigators have reported significant improvement concerning sitting, standing, extremity function and walking after the procedure. Three randomized controlled trials we- 
re published between 1997 and 1998 and compared SDR plus physiotherapy with physiotherapy alone in group of respectively 21,14 and 12 operated children [17-19]. Two of these trials showed statistically significant advantage of SDR while the third one showed no advantage. Meta-analysis of these trials published in 2002 confirmed that SDR

reduces or eliminates spasticity and leads to overall improvement in function in operated children compared with those receiving physiotherapy alone. However, since that time several papers questioning the legitimacy of SDR have been published. Therefore in the recent period new analysis of SDR efficacy have been performed.

Analysis of the results obtained by us revealed significant reduction of spasticity in the group of 30 children one year after surgery. The reduction took place in all muscle groups of lower extremities. Furthermore, statistically assessed effect size (d) of the procedure for each muscle group was large. Our results are in agreement with the results published to date. In this scope the benefit of surgical treatment is unquestionable. Although spasticity improvement cannot be directly related to general functioning, this effect of the surgery should not be underestimated. Long lasting elevated muscle tone leads to joints deformation, tendons shortening and impaired development of muscles necessitating subsequently several orthopedic procedures. These phenomena have significant negative influence on quality of life. It has been reported that quality of life is still improved 20-28 years after SDR and pain significantly reduced 17 years after SDR [20,21]. Therefore this benefit should be stressed in the discussion concerning rationals for this procedure.

However, these evidence are often considered to be inadequate due to inconsistent results regarding gross motor function after SDR. It was the reason why in 2014, NHS England commissioned a prospective evaluation of the procedure. Results of this study, published in 2019, led to national policy decision that SDR would be founded for eligible children in England. The evaluation showed GMFM-66 scores increased in almost all children from before surgery to 2 years after surgery and the mean annual increase was significant. The overall increase was 3.2 units per year. In the group of our patients mean preoperative value of GFMF was 68.62 and it rose in one year to 77.82 . The difference is statistically significant and has a medium effect size. The findings are consistent with cited above NHS England commissioned study with metaanalysis of three randomized cohort trials and other recently published analysis $[17-19,22,23,24]$. This data strongly support SDR as a valuable treatment for permanently alleviating lowerlimb spasticity and improving motor functions.

Several types of complications related to SDR were reported in the literature such as cerebrospinal fluid leak and wound infection, sensory deficits, persistent dysaesthesia, bladder dysfunction, new weakness and sudden falls [22, 25]. In our group of patients there were no significant complications and no deaths. One patient had temporary urinary retention lasting for five days. However the problem was rather catheter-related since all the patients had intra- operative neuromonitoring of sphincters and in all cases, including the problematic one, fascicles causing sphincters reaction upon stimulation were spared. Most patients reported transient paresthesia and hypersensitivity which usually improved within several days. Nevertheless this phenomenon cannot be regarded as a complication but rather as an anticipated, transient result of sensory roots manipulation and section.

The main limitation of presented study is the absence of comparison group. However, the authors of all recent analysis faced the same problem since the evidence given for the effectiveness of SDR from the 1990 [17-19] creating the control group is unlikely to be acceptable. Therefore age-specific normalised GMFM-66 centiles developed on healthy children in Canada are usually used as a reference. All the children selected to our investigation had stopped to benefit from rehabilitation as well as botulin injections several months before referral to our institution. This fact was the main reason for seeking surgical treatment by their caregivers. In this instance we assumed that any statistical improvement would be a proof of SDR effectiveness in comparison to non-effective treatment before surgery.

It should also be noticed that of 76 patients who were eligible for the study and invited for one-year follow up assessment, only 30 arrived. In the other 46 cases, parents of operated patients usually explained that they did not need the additional appointment due to good condition of the child. This phenomenon can also influence final statistical results since a significant number of cases with potentially good results was not included in the analysis. On the other hand, examination of the patients by physiotherapists involved in the treatment could contribute to the analysis bias. The results of treatment assessed one year after surgery are also influenced by the type and intensity of postoperative rehabilitation. In this perspective it should be stressed that the analyzed group is composed of patients treated at the beginning of rhizotomy program in our institution. At that time it was still a novel type of treatment in Poland and there were no rehabilitation centers prepared for and experienced in post-rhizotomy rehabilitation. Evaluated children underwent seven days of post-operative treatment in our department and subsequently received rehabilitation in different facilities. The quantity and quality of this rehabilitation was differentiated and is a confounder which cannot be accounted for. However, in this perspective, our study reflects real clinical practice and provides a picture of actual function and possibilities of the service in our country. It should be expected that with larger patients load and growing experience in physiotherapy centers the postoperative treatment will become more unified and its final results will be continuously improving.

\section{CONCLUSIONS}

To our knowledge this is the first report on results of SDR for cerebral palsy related spasticity in Polish population. In 30 analyzed patients there were no serious postoperative complications. The treatment significantly diminished spasticity and improved gross motor functioning on the long 
term basis. The improvement obtained by us was similar to that reported by other centers on the world. This should provide reassurance to parents considering the procedure and influence the discussion on including SDR to the group of neurosurgical procedures founded by health system authorities in Poland.

\section{REFERENCES:}

[1] Cans C.: Surveillance of cerebral palsy in Europe: a collaboration of cerebral palsy surveys and registers. Dev Med Child Neurol 2000; 42: 816-824.

[2] Graham D., Aquilina K., Cawker S., et al.: Single-level selective dorsal rhizotomy for spastic cerebral palsy. J Spine Surg 2016; 2: 195-201.

[3] Novak I., Mcintyre S., Morgan C., et al.: A systematic review of interventions for children with cerebral palsy: state of the evidence. Dev Med Child Neurol 2013; 55: 885-910.

[4] Aquilina K., Graham D., Wimalasundera N.: Selective dorsal rhizotomy: an old treatment reemerging. Arch Dis Child 2017; 102: 278-278.

[5] Narayanan U.G.: Management of Children With Ambulatory Cerebral Palsy: An Evidencebased Review. J Pediatr Orthop 2012; 32: 172-181.

[6] Tedroff K., Löwing K., Jacobson D.N., et al.: Does loss of spasticity matter? A 10-year follow-up after selective dorsal rhizotomy in cerebral palsy. Dev Med Child Neurol 2011; 53:724-729.

[7] Macwilliams B.A., Johnson B.A., Shuckra A.L., et al.: Functional decline in children undergoing selective dorsal rhizotomy after age 10. Dev Med Child Neurol 2011; 53: 717-723.

[8] Ashworth B.: Preliminary trial of carisoprodol in multiple sclerosis. Practitioner 1964; 192: 540-542.

[9] Bohannon R.W., Smith M.B.: Interrater reliability of a modified Ashworth scale of muscle spasticity. Phys Ther 1987; 67: 206-207.

[10] Ansari N.N., Naghdi S., Arab T.K., et al.: The interrater and intrarater reliability of the Modified Ashworth Scale in the assessment of muscle spasticity: limb and muscle group effect. NeuroRehabilitation 2008; 23: 231-237.

[11] Mutlu A., Livanelioglu A., Gunel M.K.: Reliability of Ashworth and Modified Ashworth scales in children with spastic cerebral palsy. BMC Musculoskelet Disord 2008; 9(1): e44.
[12] Palisano R., Rosenbaum P., Walter S., et al.: Development and reliability of a system to classify gross motor function in children with cerebral palsy. Dev Med Child Neurol 1997; 39: 214-223.

[13] Palisano R.J., Hanna S.E., Rosenbaum P.L., et al.: Validation of a model of gross motor function for children with cerebral palsy. Phys Ther 2000; 80: 974-985.

[14] Park T.S., Johnston J.M.: Surgical techniques of selective dorsal rhizotomy for spastic cerebral palsy. Neurosurg Focus 2006; 21(2): e7.

[15] Cohen J.: A power primer. Psychol Bull 1992; 112: 155-159.

[16] Holm S.: A simple sequentially rejective multiple test procedure. Scand J Stat 1979; 6: 65-70.

[17] Steinbok P., Reiner AM, Beauchamp R.: A randomized clinical trial to compare selective posterior rhizotomy plus physiotherapy with physiotherapy alone in children with spastic diplegic cerebral palsy. Dev Med Child Neurol 1997;39:178-184.

[18] Wright F.V., Sheil E.M., Drake J.M., et al: Evaluation of selective dorsal rhizotomy for the reduction of spasticity in cerebral palsy: a randomized controlled trial. Dev Med Child Neurol 1998; 40: 239-247.

[19] McLaughlin J.F., Bjornson K.F., Astley S.J. et al.:Selective dorsal rhizotomy: efficacy and safety in an investigator-masked randomized clinical trial. Dev Med Child Neurol. 1998;10: 220-232

[20] Terfoff K., Lowing K., Astrom E.: A prospective cohort study investigating gross motor function, pain, and health-related quality of live 17 years after selective dorsal rhizotomy in cerebral palsy. Dev Med Child Neurol 2015; 57: 484-490.21. Park T., Liu J.L., Edwards C., et al.: Functional Outcomes of Childhood Selective Dorsal Rhizotomy 20 to 28 Years Later. Cureus 2017; 9(5): e1256.

[22] Summers J., Coker B., Eddy S.: Selective dorsal rhizotomy in ambulant children with cerebral palsy: an observational cohort study. Lancet Child Adolesc Health 2019; 3: 455-462.

[23] Mittal S., Farmer J.P., Al-Atassi B.: Long-term functional outcome after selective posterior rhizotomy.. J Neurosurg 2002; 97: 315-325.

[24] Iorio-Morin C., Yap R., Dudley R.W.: Selective Dorsal Root Rhizotomy for Spastic Cerebral Palsy: A Longitudinal Case-Control Analysis of Functional Outcome. Neurosurgery (in press).

[25] Grootveld L.R., Schie P.E., Buizer A.I.: Sudden falls as a persistent complication of selective dorsal rhizotomy surgery in children with bilateral spasticity: report of 3 cases. J Neurosurg Pediatr 2016; 18: 192-195.

\section{Corresponding author:}

Leszek Sagan, Department of Neurosurgery and Pediatric Neurosurgery, Pomeranian Medical University, 1 Unii Lubelskiej Str. , 71 -252 Szczecin, Poland, e-mail: leszekm.sagan@gmail.com 